\title{
Bioengineered Skin: The Self-Assembly Approach
}

\author{
Jessica Jean ${ }^{1,2}$, Martha Estrella Garcia-Pérez ${ }^{1,2}$ and Roxane Pouliot ${ }^{1,2 *}$
}

${ }^{1}$ Centre LOEX de I'Université Laval, Génie tissulaire et régénération, LOEX - Centre de recherche FRSQ du Centre hospitalier affilié universitaire de Québec, Aile-R, 140118 e rue, Québec, Québec, Canada, G1J $1 Z 4$

${ }^{2}$ Faculté de Pharmacie, Université Laval, Québec, Québec, Canada, G1V OA6

\begin{abstract}
Tissue-engineered skin substitutes represent an innovative therapeutic option for the treatment of burns and skin ulcers as well as a powerful tool for fundamental research. To be efficient, in vitro skin substitutes must closely mimic human skin structures and exogenous material has to be reduced as much as possible. The self-assembly approach is based on the capacity of fibroblasts to create their own extracellular matrix in vitro, which allows the production of cell sheets that are easy to handle. Therefore, a skin substitute devoid of exogenous extracellular matrix proteins and synthetic material is produced, which demonstrates many histological, physico-chemical and mechanical characteristics found in normal human skin in vivo. A particularity of this approach is the possibility to add various other cell types (keratinocytes, melanocytes, adipocytes, endothelial and immunological cells, etc.) according to needs. Furthermore, pathological cells (hypertrophic scar, sclerodermic, tumoral and psoriatic cells) can be used for the production of pathological skin substitutes. The development of these models represents a key component in the fight against such diseases because they can lead to a better understanding of the pathology and to the development of new pharmaceutical therapies. This review will present the need for tissue-engineered skin substitutes, the implication of tissue engineering in the cutaneous field (basic and applied research), the selfassembly approach and its characteristics as well as the actual state of research on healthy and pathological selfassembled skin models.
\end{abstract}

Keywords: Tissue engineering; Skin substitutes; Self-assembly approach

\section{Introduction}

Diseases, congenital defects or trauma can impair organ and tissue functions [1]. These damages affect individual physical and psychological well-being and cause health problems. Replacement, repair or regeneration of the impaired organ is a way to counter this situation [1]. Since the 50s, improvements in organ transplantation, such as the appearance of innovative surgical techniques, new supply sources and the development of immunosuppressive treatments, have contributed to the success ratio of modern transplant. In 1954, Dr. Joseph Murray performed the first successful living-related kidney transplant between two identical twins. The next organs to be successfully transplanted were the lungs in 1963 by Dr. James Hardy followed by the pancreas (1966), liver (1967), heart (1967), hand (1998) and full face (2010) transplants [2]. In the United States, more than 475000 organ transplants have been done in the last 23 years. More than 28000 of those transplants occurred in 2009, when nearly 15000 people donated organs [3]. Now, organ transplants, autograft and prosthetic implants are commonly used to replace or to repair an organ. However, the need for donated organs greatly exceeds their availability, organ waiting lists are growing, and patients die expecting available organs [3].

\section{The need for tissue-engineered substitutes}

Recent biotechnological progress suggests that tissue engineering is an interesting approach to counteract organ deficit [4]. Effectively, tissue-engineered techniques allow to produce, in vitro, a large variety of organs and tissues (cartilage, cornea, blood vessels, skin, etc.) for a broad spectrum of applications: orthopaedic, pneumologic, ophthalmologic, urologic, neurologic, vascular, stem cells and dermatologic. Tissue engineering increasingly focuses on the development of biological substitutes, in order to restore, maintain or repair the tissue functions $[5,6]$. It can also help to improve our understanding of the interactions and structure of healthy and pathological tissues [7]. Tissue engineering encompasses a multitude of techniques including biomaterials, cells, growth factors and engineering components such as pumps, tubes, bioreactors and oxygenators [8]. Cells used in the production of tissues can be of diverse origins (xenogeneic, allogeneic or autogeneic). The production of autologous substitutes, from a patient's own cells, circumvents the risk of disease transmission between donor and receiver. Furthermore, autologous substitutes also prevent rejection of the graft with no need for immunosuppressive therapy.

\section{Tissue engineering vs. cutaneous field}

Tissue-engineered skin substitutes represent an innovative therapeutic option for the treatment of burns and skin ulcers as well as a powerful tool for fundamental research $[7,9]$. In fact, they can be used as a replacement for human skin in clinical applications and in various fields of fundamental research such as skin biology, pharmacotoxicology as well as cellular and molecular biology $[7,9]$. Reconstructed skin substitutes produced by tissue engineering are mostly used for the treatment of burn victims [10]. Each year, more than 2 million of American patients need medical care following burns. Among them, 20000 will suffer severe burns and will necessitate hospital admission in a burn unit [9]. Available skin donor sites may be very limited in extensive burn patients and simple autografting techniques are often not possible. Various commercially available products can

*Corresponding author: Roxane Pouliot, Ph.D., Centre LOEX de I'Université Laval, Génie Tissulaire et régénération : LOEX - Centre de recherche FRSQ du Centre hospitalier affilié universitaire de Québec, Aile-R, $140118 \mathrm{e}$ rue, Québec, Québec, Canada, G1J 1Z4, Tel: (1) 418-990-8255 ext. 1706; Fax: (1) 418-9908248; E-mail: roxane.pouliot@pha.ulaval.ca

Received June 15, 2011; Accepted October 19, 2011; Published October 21, 2011

Citation: Jean J, Garcia-Pérez ME, Pouliot R (2011) Bioengineered Skin: The SelfAssembly Approach. J Tissue Sci Eng S5:001. doi:10.4172/2157-7552.S5-001

Copyright: (c) 2011 Jean J, et al. This is an open-access article distributed under the terms of the Creative Commons Attribution License, which permits unrestricted use, distribution, and reproduction in any medium, provided the original author and source are credited. 
Citation: Jean J, Garcia-Pérez ME, Pouliot R (2011) Bioengineered Skin: The Self-Assembly Approach. J Tissue Sci Eng S5:001. doi:10.4172/21577552.S5-001

provide temporary wound cover. However, only those that incorporate living autologous keratinocytes and epidermal stem cells can lead to the formation of a permanent, self-sustaining epidermis. This has fostered the development of alternative approach such as skin substitutes [9]. Effectively, from a small biopsy of skin, tissue engineering allows the production of many skin substitutes which can also be used in the treatment of skin ulcers. Diabetic ulcers affect $4.4 \%$ to $10.5 \%$ of diabetic patients, resulting in 82000 lower extremity amputations each year; venous leg ulcers touch $0.2 \%$ to $1.4 \%$ of the world population whereas the prevalence of pressure ulcers is estimated to $5.0 \%$ to $8.8 \%$ of institutionalized patients [8]. Skin substitutes are an interesting way to counter these problems.
Such as previously mentioned, another considerable aspect of tissue engineering is its usefulness for fundamental research. In vitro production of skin substitutes may be useful to test new treatments or to better understand cell mechanisms (cell proliferation and differentiation, inflammation, intercellular interactions, etc.) [11]. Normal skin substitutes are mainly used for dermopharmaceutical, pharmacotoxicological and, sometimes, for physiological assays [12]. A broad variety of normal skin substitutes are commercially available for clinical applications and fundamental research. Each type of substitutes has its advantages and inconvenients. An exhaustive list of substitutes currently available on the market is presented in Table 1 including clinical applications and fundamental research references.

\begin{tabular}{|c|c|c|}
\hline Commercial product & Description & References \\
\hline \multicolumn{3}{|l|}{ Epidermal substitutes } \\
\hline BioSeed-S ${ }^{\mathrm{TM}}$ & Subconfluent autologous keratinocytes on a fibrin matrix & {$[14,15]$} \\
\hline CellSpray ${ }^{\top \mathrm{M}}$ & Noncultured autologous keratinocyte suspension & - \\
\hline Cryoskin $^{\mathrm{TM}}$ & Cryopreserved monolayer of noncultured allogeneic keratinocytes coating with silicone backing & {$[16,17]$} \\
\hline Epibase & Cultured autologous keratinocytes & {$[18,21]$} \\
\hline Epicel $^{\otimes}$ & Cultured autologous keratinocytes from skin on petrolatum gauze backing & {$[8,22,23]$} \\
\hline Epidex ${ }^{\top \mathrm{M}}$ & Cultured autologous keratinocytes from the outer root sheath on silicone membrane & [24-26] \\
\hline Episkin $^{\top M}$ & Cultured keratinocytes on a collagen matrix & [27-29] \\
\hline Laserskin $^{\mathrm{TM}}\left(\right.$ Vivoderm $\left.^{\mathrm{TM}}\right)$ & Cultured autologous keratinocytes in a matrix of a hyaluronic acid ester & {$[30-37]$} \\
\hline LyphoDerm $^{\mathrm{TM}}$ & Freeze-dried lysate from cultured allogeneic epidermal keratinocytes into a hydrophilic gel & [38] \\
\hline Myskin $^{\top M}$ & Cultured autologous keratinocytes seeded on specially treated silicone sheet & {$[39,40]$} \\
\hline ReCell ${ }^{\circledR}$ & Noncultured autologous keratinocyte suspension & [41-45] \\
\hline Suprathel ${ }^{\circledR}$ & Absorbable, synthetic wound dressing with properties of natural epithelium & [46-48] \\
\hline \multicolumn{3}{|l|}{ Dermal substitutes } \\
\hline AlloDerm ${ }^{\mathrm{TM}}$ & Allogeneic acellular dermal matrix & [49-54] \\
\hline Biobrane $^{\mathrm{TM}}$ & Porcine collagen chemically bound to silicone/nylon membrane & [55-58] \\
\hline 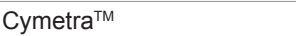 & Micronized particulate acellular cadaveric dermal matrix & [59] \\
\hline Dermagen & Allogeneic fibroblasts cultured in a collagenous sponge & [60] \\
\hline Dermagraft ${ }^{\mathrm{TM}}$ & Allogeneic living human-derived fibroblast skin substitute & {$[54,61-63]$} \\
\hline Dermamatrix & Allogeneic acellular human dermis & {$[49,50]$} \\
\hline EZ-Derm ${ }^{\mathrm{TM}}$ & Acellular xenogeneic collagen matrix & {$[64,65]$} \\
\hline FortaFlex $^{\mathrm{TM}}$ & Acellular collagen matrix material derived from porcine small intestine submucosa & - \\
\hline Glyaderm $^{\circledR}$ & Acellular human dermis & {$[66,67]$} \\
\hline 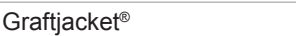 & Allogeneic human acellular pre-meshed dermis & {$[68-70]$} \\
\hline Hyalograft $3 \mathrm{D}^{\mathrm{TM}}$ & Autologous dermal substitute including a matrix of a hyaluronic acid ester & {$[30,31,71,72]$} \\
\hline ICX-SKN & Allogeneic dermal substitute with human dermal fibroblasts in human collagen matrix & {$[73,74]$} \\
\hline Integra ${ }^{\circledR}$ & Nonliving extracellular matrix of collagen and chondroitin-6-sulfate with silicone backing & {$[45,75-82]$} \\
\hline Karoderm & Allogeneic human acellular dermis & - \\
\hline Matriderm $^{\mathrm{T} M}$ & Acellular scaffold composed of elastin and collagen types I, III and V & [83-88] \\
\hline Oasis ${ }^{\mathrm{TM}}$ & Acellular collagen matrix material derived porcine small intestinal submucosa & [89-91] \\
\hline Permacol Surgical Implant & Acellular porcine dermis & [92-94] \\
\hline Repliform $^{\mathrm{TM}}$ & Acellular cadaveric human dermal allograft & [95] \\
\hline Strattice $^{\mathrm{TM}}$ & Acellular porcine dermis & [96-99] \\
\hline SureDerm & Allogeneic acellular human lyophilized dermis & {$[100,101]$} \\
\hline TransCyte ${ }^{T M}$ & $\begin{array}{l}\text { Polymer membrane and allogeneic neonatal human fibroblast cells on a nylon mesh coated with porcine } \\
\text { dermal collagen and bonded to a polymer membrane (silicone) }\end{array}$ & [102-106] \\
\hline \multicolumn{3}{|l|}{ Bilayer substitutes } \\
\hline Apligraf ${ }^{\oplus}$ & Allogeneic cultured human keratinocytes and fibroblasts in a bovine collagen sponge & [107-109] \\
\hline OrCel $^{\circledR}$ & Similar to Apligraf ${ }^{\circledast}$ & {$[110,111]$} \\
\hline PermaDerm ${ }^{\mathrm{TM}}$ & $\begin{array}{l}\text { Autologous keratinocytes seeded onto dermal substitute made with autologous fibroblasts in bovine } \\
\text { collagen matrix }\end{array}$ & {$[112,113]$} \\
\hline PolyActive & $\begin{array}{l}\text { Autologous cultured keratinocytes and fibroblasts in elastomeric and biodegradable polyethylene oxide } \\
\text { terephthalate/polybutylene terephthalate copolymer }\end{array}$ & {$[114,117]$} \\
\hline StrataGraft ${ }^{\circledR}$ & $\begin{array}{l}\text { Allogeneic dermis and epidermis generated from a progenitor cell line: neonatal immortalized } \\
\text { keratinocytes }\left(\mathrm{NIKS}^{\oplus}\right)\end{array}$ & {$[118,119]$} \\
\hline TissueTech ${ }^{T M}$ & $\begin{array}{l}\text { Autologous dermal substitute Hyalograft 3D combined with an autologous epidermal replacement } \\
\text { (Laserskin autograft) }\end{array}$ & {$[31,120]$} \\
\hline
\end{tabular}

Table 1 : Commercially available skin substitutes. 
Skin substitutes can also be pathological. In vitro pathological models are a good alternative to animal models. These models are produced with pathological cells, in order to mimic the main features of the pathology. Their main functions include: (1) testing new drugs and (2) performing pathophysiological studies in order to better understand the underlying mechanisms of the pathology. However, many of these models do not mimic closely enough the pathological characteristics of interest and researchers stay alert for the development of more relevant pathological models [13].

\section{Self-assembly approach}

To be effective, in vitro skin substitutes must closely mimic human skin structure [121] and exogenous materials has to be reduced as much as possible. The self-assembly approach allows the production of skin substitutes devoid of exogenous extracellular matrix proteins and synthetic materials that also demonstrate many histological, physicochemical and mechanical characteristics found in normal human skin in vivo [13].

\section{Self-assembly approach methodology}

In the self-assembly approach, fibroblasts are cultured in the presence of ascorbic acid $(50 \mu \mathrm{g} / \mathrm{mL})$ for 4 weeks, thus forming manipulatable sheets, which are superimposed and incubated for 7 days to form the dermal component. After 7 days of culture, keratinocytes can be seeded upon this tissue to form the epidermal layer. After another 7 days of culture, the substitutes are raised to the air-liquid interface [122,123]. Biopsies are taken after 7, 14 and/or 21 days of culture at the air-liquid interface and analyzed using histological, immunohistochemical, permeability or physico-chemical techniques (Figure 1).

\section{Self-assembly approach characteristics}

As previously reported, substitutes produced with the self-assembly approach share many characteristics with normal human skin. These features will be discussed in this section.

First, self-assembled skin substitutes possess many histological characteristics close to those observed in normal human skin, such as the presence of both dermis and epidermis. The reconstructed epidermis is well-differentiated, including the presence of all epidermal layers of the native tissue: stratum basale, stratum spinosum, stratum granulosum and stratum corneum (Figure 2) [122,123]. The reconstructed dermis is well-colonized by the fibroblasts, which synthesize an abundant extracellular matrix [7]. Epidermal thickness varies in function of culture time whereas the dermal thickness differs according to the number of superimposed fibroblast sheets used (see Section of the selfassembly approach).

Second, expression (and localization) data for many proliferation and differentiation markers, as well as dermo-epidermal and extracellular markers, revealed that skin substitutes produced with the self-assembly approach share common structures with normal human skin (Table 2) [124]. Effectively, in both normal human skin and selfassembled skin substitutes, the expression of involucrin appears in the late spinous layer of the epidermis whereas loricrin is expressed in the granular layer (Figure 3A) [11]. Collagen I and III, two constituents of the extracellular matrix, are expressed in a similar way in the dermis of normal human skin and in the self-assembled skin substitutes (Figure 3B) [11]. Finally, markers of the dermo-epidermal junction, such as laminin V and human collagen type VII, are expressed in the dermoepidermal junction of self-assembled substitutes such as what can be observed in normal human skin (Figure 4) [11].

Third, stratum corneum is the primary protective barrier of the organism against chemical and biological external agents as well as water loss [125]. Well-structured lipid organization and impermeability of the stratum corneum are two essential criteria to obtain valuable tissue-engineered skin substitutes. Previous study using ATR-FTIR techniques had demonstrated that self-assembled skin substitutes possess an efficient lipid organization in the stratum corneum, much better than that observed in collagen gel skin substitutes. Effectively, self-assembled skin substitutes show lower frequencies in $\mathrm{CH}_{2}$ bands compared with collagen gel substitutes and higher frequencies when compared with normal human skin (Figure 5) [4]. Higher frequencies in $\mathrm{CH}_{2}$ bands are generally characteristic of high content of gauche conformers while bands at lower frequencies are associated to the presence of trans conformers. The variation of frequencies in function of the temperature shows a phase transition from an ordered system to a disordered conformation [11]. The results generated by the study of lipid organization in the stratum corneum can be summarized as follows: collagen gel substitutes < self-assembled skin substitutes < normal human skin.

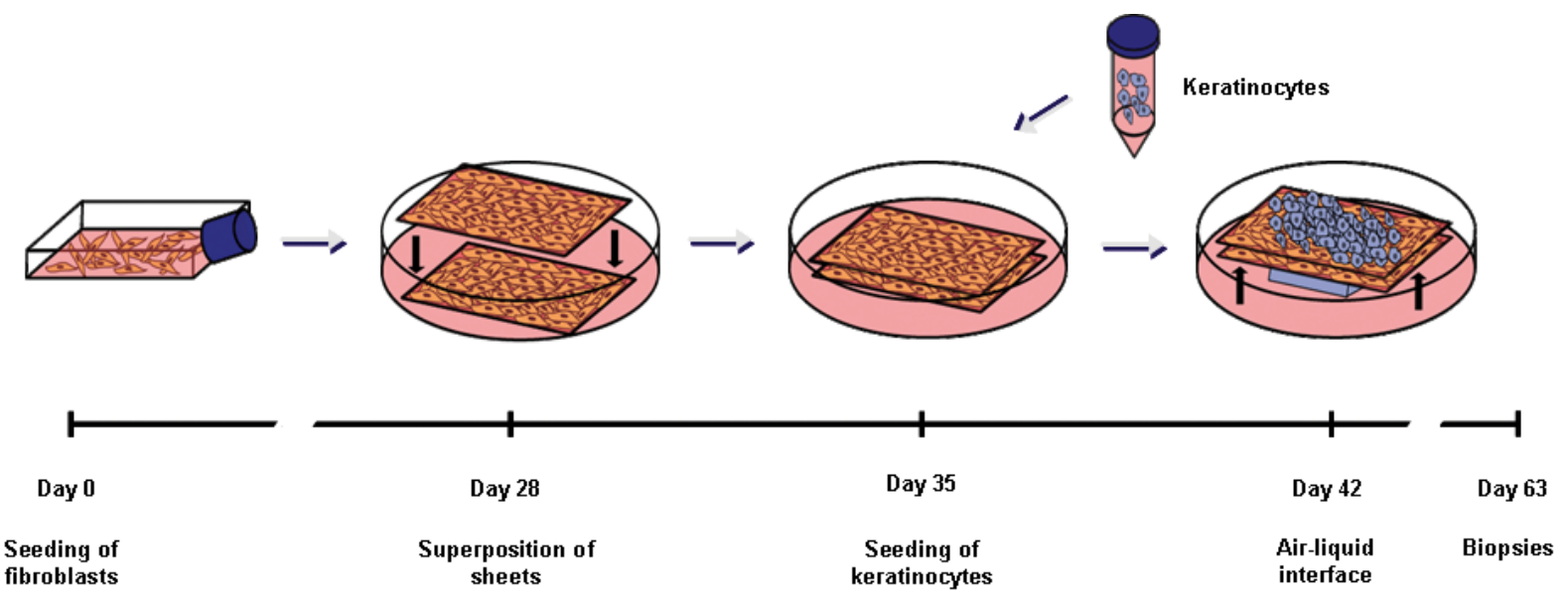

Figure 1: Self-assembly approach. Schematic representation of the various steps of skin substitutes production in function of time. Reproduced and modified from Jean et al., 2010 according to the copyright policy of the publisher. (c) $2010 \mathrm{InTech}$. 


\begin{tabular}{|l|l|l|}
\hline Markers & Expression & \\
\hline Epidermal & & Skin substitute \\
\hline Keratins 5 and 14 & SB & SB; SSB \\
\hline Keratins 1 and 10 & SSB & SSB \\
\hline Involucrin & SP; SG & SP; SG (Figure 3A) \\
\hline Transglutaminase & SP; SG & SP; SG \\
\hline Loricrin & SG & SP; SG (Figure 3A) \\
\hline Filaggrin & SG & SP; SG \\
\hline DLK & SG & SG \\
\hline Dermo-epidermal & & \\
\hline Laminin V & BM & BM (Figure 4) \\
\hline Collagen IV & BM & BM; dermis \\
\hline Collagen VII & BM & BM (Figure 4) \\
\hline Dermal & & \\
\hline Collagen I & Dermis & Dermis (Figure 3B) \\
\hline Collagen III & Dermis & Dermis (Figure 3B) \\
\hline Fibronectin & Dermis & Dermis \\
\hline
\end{tabular}

SB: stratum basale; SP: stratum spinosum; SG: stratum granulosum; SC: stratum corneum; SSB: stratum suprabasale; BM: basement membrane

Table 2: Expression of epidermal, dermo-epidermal and dermal markers in human skin and in skin substitute produced with the self-assembly approach.

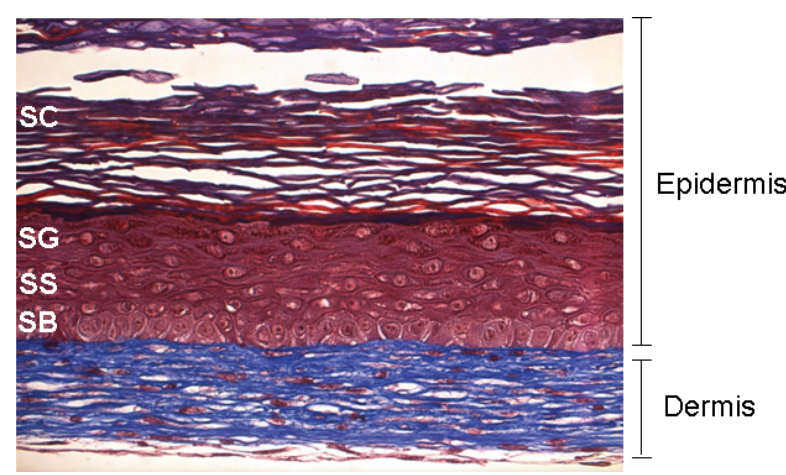

Figure 2: Histological features of self-assembled skin substitutes. Masson's trichrome staining of tissue-engineered skin substitutes produced with the self-assembly approach and cultured 21 days at the air-liquid interface. Magnification 40X. SB: stratum basale, SS: stratum spinosum, SG: stratum granulosum, SC: stratum corneum.

Finally, permeability results obtained by percutaneous absorption analyses demonstrate that self-assembled skin substitutes possess an impressive impermeability profile, close to that observed in normal human skin, as measured with a lipophilic molecule such as hydrocortisone (Figure 6) [11].

\section{Self-assembly approach for clinical use and fundamental research}

Normal skin substitutes can be used to cover burns, skin ulcers and also serve as in vitro models in various fields of fundamental research including skin biology, pharmacotoxicology as well as in cell and molecular biology studies $[7,9,10]$. Normal skin substitutes are produced with autologous normal cells. On the other hand, pathological skin substitutes can also be produced with the selfassembly approach by using pathological cells of various skin diseases. These substitutes are not used as a replacement for clinical applications, but as pathological models for preclinical studies, to better understand mechanisms of diseases and to observe the effects of new treatments. Pathological self-assembled skin substitutes display some cell-specific pathological characteristics of the affected tissues from which the cells were extracted, such as hypertrophic scars, psoriasis and scleroderma $[13,126,127]$. For example, in 2009, Jean et al., demonstrated that psoriatic substitutes produced with the self-assembly approach maintained many characteristics of the disease including the presence of a disorganized and thicker epidermis compared with normal skin substitutes. These observations suggest the presence of keratinocyte hyperproliferation and abnormal differentiation that characterize psoriatic skin in vivo (Figure 7) [13]. So far, many cell types are used for the production of self-assembled skin substitutes and three skin diseases can be partially reproduced. A list of normal and pathological cell types used for the production of self-assembled substitutes is presented in Table 3 .

Overall, the self-assembly approach allows the understanding of pathological skin complexity through the possibility of: (1) dissecting step by step the mechanisms of skin pathologies according to which kind of cells is present in the model at this time and/or (2) using various cell combinations such as healthy fibroblasts and healthy keratinocytes, which can be compared with healthy fibroblasts and pathological

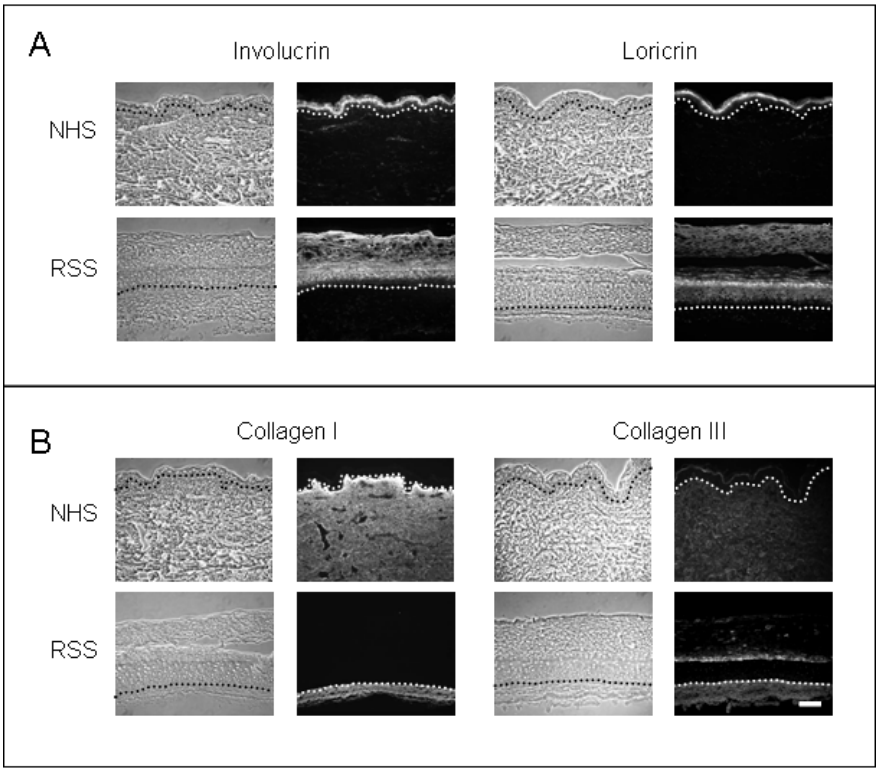

Figure 3: Epidermal and dermal immunohistochemical analyses of skin substitutes. Immunolabelling of epidermal differentiation markers (A) and extracellular matrix (B) of substitutes produced with the self-assembly approach. NHS: normal human skin; RSS: reconstructed skin substitute (scale bar $=50 \mu \mathrm{m})$. The dotted line indicates the dermo-epidermal junction. Reproduced and modified from Jean et al., 2011 according to the copyright policy of the publisher. (c) 2011 Mary Ann Liebert, Inc.

\begin{tabular}{|l|l|}
\hline Cell types & References \\
\hline Normal cells & \\
\hline Adipocyte & {$[128-131]$} \\
\hline Endothelial & {$[132]$} \\
\hline Melanocyte & - \\
\hline Stem & {$[133-136]$} \\
\hline Pathological cells & \\
\hline Hypertrophic scar & {$[126]$} \\
\hline Psoriatic & {$[4,13,137]$} \\
\hline Sclerodermic & {$[127]$} \\
\hline
\end{tabular}

Table 3: Normal and pathological cell types used for the production of skin substitutes produced with the self-assembly approach. 


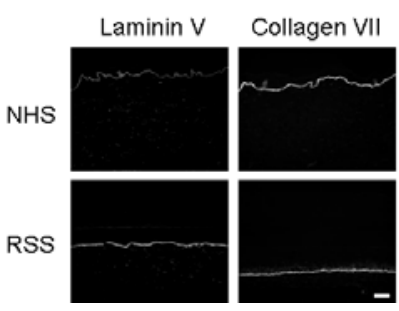

Figure 4: Immunohistochemical analyses of the dermo-epidermal junction of skin substitutes. Immunolabelling of the dermo-epidermal junction: laminin $\mathrm{V}$ and collagen VII of skin substitutes produced with the self-assembly approach. NHS: normal human skin; RSS: reconstructed skin substitute (scale bar $=50 \mu \mathrm{m}$ ). Reproduced and modified from Jean et al., 2011 according to the copyright policy of the publisher. (c) 2011 Mary Ann Liebert, Inc.

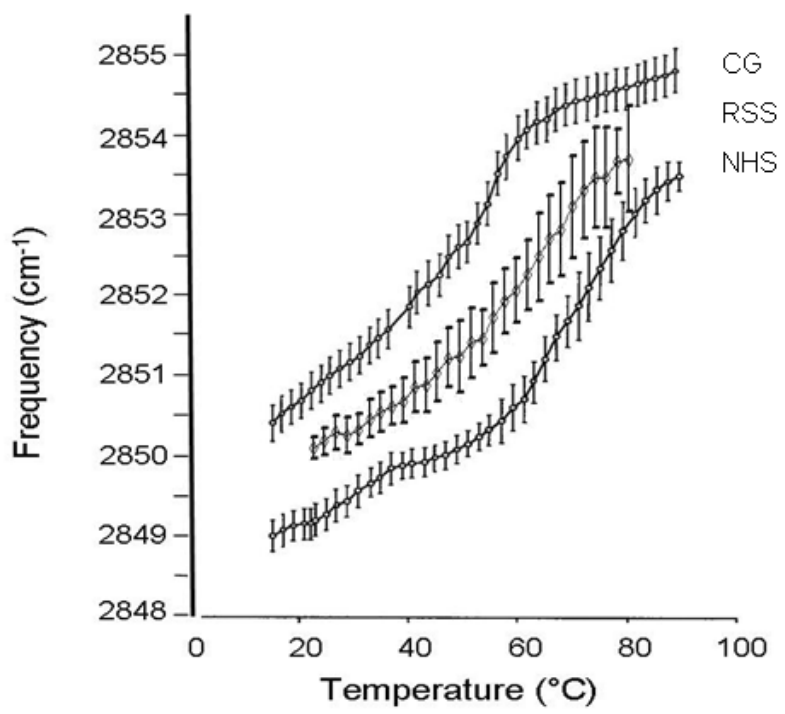

Figure 5: Comparison of the stratum corneum lipid organization of collagen gel substitute, self-assembled skin substitute and normal human skin. ATR-FTIR spectroscopy results obtained from collagen gel skin substitute (CG), self-assembled skin substitutes (RSS) and normal human skin (NHS). Reproduced and modified from Bernard et al., 2007 according to the copyright policy of the publisher. (c) 2007 Elsevier.

keratinocytes to analyse the interaction between different cell types [138]. These combinations are not observed in vivo and could only be studied with in vitro skin models.

\section{The self-assembly approach compared with other skin substitute models}

Commercially available skin substitutes are grouped into three categories: epidermal, dermal and bilayer skin substitutes. Reconstructed skin substitutes produced with the self-assembly approach can be included in the bilayer category, because they are composed of both dermis and epidermis. This category includes six models characterized by the presence of autologous or allogeneic cells cultured with exogenous material. In fact, Apligraft ${ }^{\circledR}$ and $\mathrm{OrCel}^{\circledR}$ are produced with allogeneic human keratinocytes and fibroblasts, cultured in a bovine collagen sponge [107-111] whereas other bilayer skin models are produced with autologous keratinocytes, seeded onto a dermal substitute made with autologous fibroblasts in a bovine collagen $\left(\right.$ PermaDerm $\left.{ }^{\mathrm{TM}}\right)[112,113]$, hyaluronic acid ester $\left(\right.$ TissueTech $\left.^{\mathrm{TM}}\right)[31,120]$ or polymer (Polyactive)
[114-117] matrix. As for the StrataGraft ${ }^{\circledR}$ model, it is produced with allogeneic dermis and epidermis generated from a progenitor cell line: neonatal immortalized keratinocytes $\left(\mathrm{NIKS}^{\circledR}\right)$ cultured in a non-bovine source of purified type I collagen [118,119]. Although only Apligraft ${ }^{\mathbb{R}}$, $\mathrm{OrCel}^{\circledR}$ and StrataGraft ${ }^{\mathbb{R}}$ use allogeneic keratinocytes and fibroblasts, all six commercially bilayer skin models are characterized by the use of exogenous material to produce the dermal matrix. Self-assembled reconstructed skins share some features with commercially available bilayer skin substitutes. However, they set themselves apart from the others because: (1) they are produced with autologous cells and (2) they are completely free of exogenous biomaterials, thus eliminating risks of rejection, infection or immune reactions [7]. An exogenousfree materials are clearly advantageous for clinical applications and laboratory research, but its production is time-consuming. Indeed, the production of a complete autologous extracellular matrix necessitates

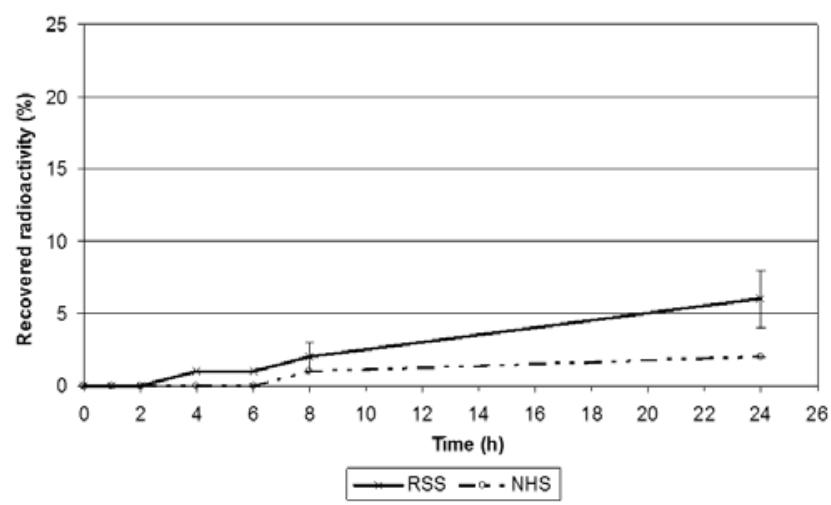

Figure 6: Comparison of the percutaneous absorption of selfassembled skin substitute and normal human skin. Hydrocortisone penetration profiles through skin of self-assembled skin substitute and normal human skin. NHS: normal human skin; RSS: reconstructed skin substitute. Reproduced and modified from Jean et al., 2011 according to the copyright policy of the publisher. (C) 2011 Mary Ann Liebert, Inc.
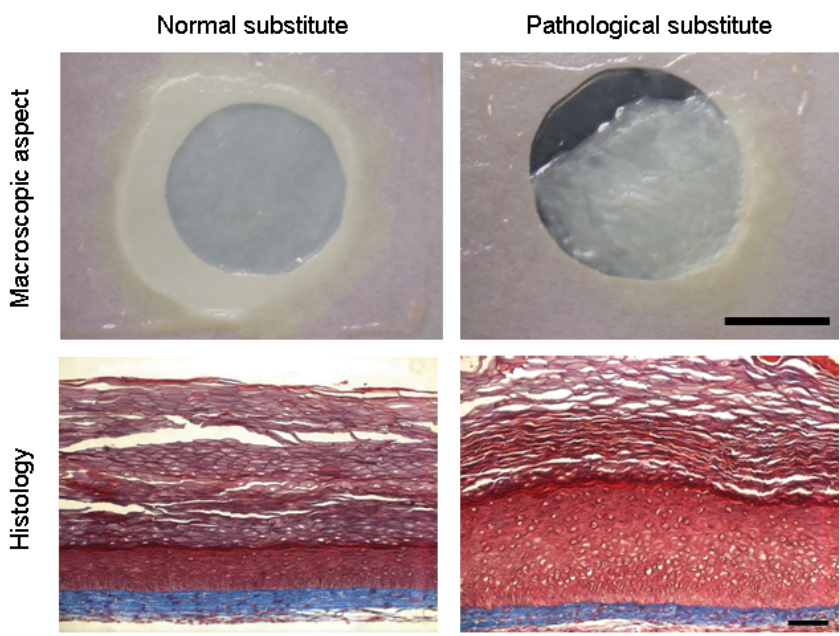

Figure 7: Macroscopic appearance and histological analysis of norma and pathological skin substitutes. Macroscopic and histological analyses of normal and pathological skin substitutes after 21 days of culture at the airliquid interface (scale bars $=2.2 \mathrm{~cm}$ and $50 \mu \mathrm{m}$, respectively). Reproduced and modified from Jean et al., 2009 according to the copyright policy of the publisher. 2009 Elsevier. 
three months of culture. Thus, substitutes produced with the selfassembly approach can be used for clinical applications if the situation allows it; however, in emergency applications where time is of the essence, commercially skin substitutes can be a good alternative.

\section{The self-assembly approach used in other tissue-engineered fields}

This review highlighted the production of skin substitutes with the self-assembly approach. However, it is important to mention that the self-assembly approach can be used in various fields of tissue engineering. Since 1990s, it has also been adapted for the production of reconstructed blood vessels, bladder and cornea [139,140]. In 1998, L'heureux et al. published data on reconstructed blood vessels produced with the self-assembly approach, which demonstrated a functional endothelium and positively reacted to surgical handling. It is important to note that this team was the first to obtain a completely biological tissue-engineered blood vessel with a burst strength comparable to what is observed in human blood vessels [139].

In 2006, Magnan et al. developed an endothelialized bladder from a single porcine biopsy [140]. They demonstrated that reconstructed bladder substitutes that possessed a thickness of at least $2 \mathrm{~mm}$, were able to promote the formation of capillary-like tubes [140] and presented an efficient permeability barrier to urea [141]. Following this accomplishment, they studied the possibility to produce urinary tracts with the self-assembly approach [142]. Interesting results were obtained regarding the possibility to test this reconstructed bladder on bigger animals [143].

Another possible application of the self-assembly approach is the production of corneas with autologous cells. The current state of knowledge shows that it is possible to produce a complete autologous tissue-engineered human cornea, similar to native corneas, using untransformed fibroblasts, epithelial and endothelial cells [144]. The self-assembly approach has already opened new horizons and the transfer of this technique to other tissue-engineering applications is probable in the near future.

\section{Conclusion}

Skin substitutes play a crucial role in both clinical applications and fundamental research. They can provide a mechanical barrier against infection and fluid loss [10] or replace animal models for dermopharmaceutical testings $[4,11]$. Skin substitutes can also lead to a better understanding of pathological and/or normal skin mechanisms [11]. There is a large variety of substitutes in the "skin substitute family", commercially available or not, and the self-assembled model is one member of this family.

\section{The self-assembly approach benefits}

Since 1990s, the self-assembly approach has been developed for the production of a broad variety of tissue-engineered substitutes (reconstructed skin, blood vessels, bladder and cornea). This approach has demonstrated many advantages compared to other models in both clinical applications and fundamental research.

\section{Clinical application benefits}

The self-assembly approach allows the production of autologous skin substitutes devoid of exogenous material. The production of autologous substitutes, from a patient's own cells, circumvents the risk of disease transmission between donor and receiver and also prevents graft rejection without the need for immunosuppressive therapy. Moreover, the absence of exogenous material eliminates risks of infection or immune reactions for patients following skin graft [7]. From a small skin biopsy, thousand of self-assembled skin substitutes can be produced. These substitutes are useful to cover a variety of large scale wounds (burns or diabetic ulcers). Finally, the major interest of the self-assembled skin substitutes is the incorporation of living autologous keratinocytes and epidermal stem cells, which can lead to the formation of a permanent, self-sustaining epidermis.

\section{Fundamental research benefits}

The self-assembly approach can be really useful for fundamental skin studies because this model allows the production of reproducible human skin substitutes, which closely mimic normal or pathological human skin structures and hallmarks. Furthermore, this model brings the possibility to produce many human skin substitutes with only a little piece of skin allowing the reduction of animal models in laboratory. The use of self-assembled skin substitutes, pathological or not, could improve our understanding of cellular complex interactions linked to cutaneous physiology, stem cells interactions, wound healing, skin diseases, dermatopharmacology and angiogenesis. Another particularity of this approach is the possibility to add many cell types according to needs [128-136]. It is also feasible to use pathological cells for the production of pathological skin substitutes $[4,13,126,127,137]$. The development of such models represents a key component in the fight against these diseases, providing tools that can lead to a better understanding of the pathology and to the development of new pharmaceutical therapies [13].

\section{Acknowledgements}

The authors gratefully acknowledge Dr. Dan Lacroix for manuscript revision. $\mathrm{RP}$ was recipient of a research fellowship from the «Fonds de la Recherche en Santé du Québec» (FRSQ) of Québec, Canada.

\section{References}

1. Dieckmann C, Renner R, Milkova L, Simon JC (2010) Regenerative medicine in dermatology: biomaterials, tissue engineering, stem cells, gene transfer and beyond. Exp Dermatol 19: 697-706.

2. Talbot D, D'Alessandro AM and Muiesan $P$ (2009) Organ donation and transplantation after cardiac death Oxford ; Toronto : Oxford University Press.

3. U.S. Department of Health \& Human Services (2011).

4. Bernard G, Auger M, Soucy J, Pouliot R (2007) Physical characterization of the stratum corneum of an in vitro psoriatic skin model by ATR-FTIR and Raman spectroscopies. Biochim Biophys Acta 1770: 1317-1323.

5. Arosarena O (2005) Tissue engineering. Curr Opin Otolaryngol Head Neck Surg 13:233-241.

6. Giannoudis PV, Pountos I (2005) Tissue regeneration. The past, the present and the future. Injury 36 Suppl 4 : S2-5.

7. Auger FA, Berthod F, Moulin V, Pouliot R, Germain L (2004) Tissue-engineered skin substitutes: from in vitro constructs to in vivo applications. Biotechnol Appl Biochem 39: 263-275.

8. Ehrenreich M, Ruszczak Z (2006) Update on tissue-engineered biological dressings. Tissue Eng 12: 2407-2424.

9. Horch RE, Kopp J, Kneser U, Beier J, Bach AD (2005) Tissue engineering of cultured skin substitutes. J Cell Mol Med 9: 592-608.

10. Priya SG, Jungvid $H$ and Kumar A (2008) Skin tissue engineering for tissue repair and regeneration. Tissue Eng Part B Rev 14:105-118.

11. Jean J, Bernard G, Duque-Fernandez A, Auger FA, Pouliot R (2011) Effects of serum-free culture at the air-liquid interface in a human tissue-engineered skin substitute. Tissue Eng Part A 17:877-888. 
12. Monteiro-Riviere NA, Inman AO, Snider TH, Blank JA, Hobson DW (1997) Comparison of an in vitro skin model to normal human skin for dermatological research. Microsc Res Tech 37:172-179.

13. Jean J, Lapointe M, Soucy J, Pouliot R (2009) Development of an in vitro psoriatic skin model by tissue engineering. J Dermatol Sci 53:19-25.

14. Vanscheidt W, Ukat A, Horak V, Brüning H, Hunyadi J, et al. (2007) Treatment of recalcitrant venous leg ulcers with autologous keratinocytes in fibrin sealant: a multinational randomized controlled clinical trial. Wound Repair Regen 15 308-315.

15. Johnsen S, Ermuth T, Tanczos E, Bannasch H, Horch RE, et al. (2005) Treatment of therapy-refractive ulcera cruris of various origins with autologous keratinocytes in fibrin sealant. Vasa 34: 25-29.

16. Beele H, de la Brassine M, Lambert J, Suys E, De Cuyper C, et al. (2005) A prospective multicenter study of the efficacy and tolerability of cryopreserved allogenic human keratinocytes to treat venous leg ulcers. Int J Low Extrem Wounds 4: 225-233.

17. Paquet P, Quatresooz P, Braham C, Pierard GE (2005) Tapping into the influence of keratinocyte allografts and biocenosis on healing of chronic leg ulcers: split-ulcer controlled pilot study. Dermatol Surg 31: 431-435.

18. Acher-Chenebaux A, Maillard H, Potier A, Nzeyimana H, Cazals F, et al. (2006) [Cutaneous calciphylaxis treated by autologous keratinocytes graft and subtotal parathyroidectomy]. Ann Dermatol Venereol 133: 260-263.

19. Vaillant $L$ (2002) [Treatment of venous leg ulcers with Epibase. A prospective study. Preliminary results]. Ann Dermatol Venereol 129: 1245-1246.

20. Martin L (2002) [Necrotic angiodermatitis treatment with epibase]. Ann Dermatol Venereol 129: 1243-1244.

21. Soler C (2002) [Genevrier Biotechnology Center: production of autologous epidermal sheets (Epibase)]. Ann Dermatol Venereol 129: 1239-1241.

22. Carsin H, Ainaud P, Le Bever H, Rives J, Lakhel A, et al. (2000) Cultured epithelial autografts in extensive burn coverage of severely traumatized patients: a five year single-center experience with 30 patients. Burns 26: 379 387

23. Wright KA, Nadire KB, Busto P, Tubo R, McPherson JM, et al. (1998) Alternative delivery of keratinocytes using a polyurethane membrane and the implications for its use in the treatment of full-thickness burn injury. Burns 24: 7-17.

24. Hafner J, Kuhne A and Trueb RM (2006) Successful grafting with EpiDex in pyoderma gangrenosum. Dermatology 212: 258-259.

25. Renner R, Harth W, Simon JC (2009) Transplantation of chronic wounds with epidermal sheets derived from autologous hair follicles--the Leipzig experience. Int Wound J 6: 226-232.

26. Tausche AK, Skaria M, Böhlen L, Liebold K, Hafner J, et al. (2003) An autologous epidermal equivalent tissue-engineered from follicular outer root sheath keratinocytes is as effective as split-thickness skin autograft in recalcitrant vascular leg ulcers. Wound Repair Regen 11: 248-252.

27. Spielmann H, Hoffmann S, Liebsch M, Botham P, Fentem JH et al. (2007) The ECVAM international validation study on in vitro tests for acute skin irritation: report on the validity of the EPISKIN and EpiDerm assays and on the Skin Integrity Function Test. Altern Lab Anim 35: 559-601.

28. Cotovio J, Grandidier MH, Portes P, Roguet R and Rubinstenn G (2005) The in vitro skin irritation of chemicals: optimisation of the EPISKIN prediction mode within the framework of the ECVAM validation process. Altern Lab Anim 33: 329-349.

29. Roguet R, Cohen C, Dossou KG, Rougier A (1994) Episkin, a reconstituted human epidermis for assessing in vitro the irritancy of topically applied compounds. Toxicol In Vitro 8: 283-291.

30. Monami M, Vivarelli M, Desideri CM, Ippolito G, Marchionni N, et al. (2011) Autologous skin fibroblast and keratinocyte grafts in the treatment of chronic foot ulcers in aging type 2 diabetic patients. J Am Podiatr Med Assoc 101 55-58.

31. Uccioli L (2003) A clinical investigation on the characteristics and outcomes of treating chronic lower extremity wounds using the tissuetech autograft system. Int $\mathrm{J}$ Low Extrem Wounds 2: $140-151$.

32. Lam PK, Chan ES, Ho WS, Liew CT (2004) In vitro cytotoxicity testing of a nanocrystalline silver dressing (Acticoat) on cultured keratinocytes. $\mathrm{Br} J$ Biomed Sci 61: 125-127.
33. Lobmann R, Pittasch D, Muhlen I, Lehnert H (2003) Autologous human keratinocytes cultured on membranes composed of benzyl ester of hyaluronic acid for grafting in nonhealing diabetic foot lesions: a pilot study. J Diabetes Complications 17: 199-204.

34. Lam PK, Chan ES, Liew CT, Lau C, Yen SC, et al. (2002) Combination of a new composite biocampatible skin graft on the neodermis of artificial skin in an animal model. ANZ J Surg 72: 360-363.

35. Chan ES, Lam PK, Liew CT, Lau HC, Yen RS, et al. (2001) A new technique to resurface wounds with composite biocompatible epidermal graft and artificial skin. J Trauma 50: 358-362.

36. Lam PK, Chan ES, To EW, Lau CH, Yen SC, et al. (1999) Development and evaluation of a new composite Laserskin graft. J Trauma 47: 918-922.

37. Andreassi L, Pianigiani E, Andreassi A, Taddeucci P, Biagioli M (1998) A new model of epidermal culture for the surgical treatment of vitiligo. Int $\mathrm{J}$ Dermato 37:595-598.

38. Harding KG, Krieg T, Eming SA, Flour ML, Jawien A, et al. (2005) Efficacy and safety of the freeze-dried cultured human keratinocyte lysate, LyphoDerm $0.9 \%$, in the treatment of hard-to-heal venous leg ulcers. Wound Repair Regen 13: $138-147$

39. Moustafa M, Bullock AJ, Creagh FM, Heller S, Jeffcoate W, et al. (2007) Randomized, controlled, single-blind study on use of autologous keratinocytes on a transfer dressing to treat nonhealing diabetic ulcers. Regen Med 2: 887902.

40. Moustafa M, Simpson C, Glover M, Dawson RA, Tesfaye S, et al. (2004) A new autologous keratinocyte dressing treatment for non-healing diabetic neuropathic foot ulcers. Diabet Med 21: 786-789.

41. Cervelli V, De Angelis B, Balzani A, Colicchia G, Spallone D, et al. (2009) Treatment of stable vitiligo by ReCell system. Acta Dermatovenerol Croat 17 : 273-278.

42. Cervelli V, De Angelis B, Spallone D, Lucarini L, Arpino A et al. (2010) Use of a novel autologous cell-harvesting device to promote epithelialization and enhance appropriate pigmentation in scar reconstruction. Clin Exp Dermato 35: $776-780$.

43. Mulekar SV, Ghwish B, Al Issa A, Al Eisa A (2008) Treatment of vitiligo lesions by ReCell vs. conventional melanocyte-keratinocyte transplantation: a pilot study. Br J Dermatol 158: 45-49.

44. Gravante G, Di Fede MC, Araco A, Grimaldi M, De Angelis B, et al. (2007) A randomized trial comparing ReCell system of epidermal cells delivery versus classic skin grafts for the treatment of deep partial thickness burns. Burns 33 966-972.

45. Wood FM, Stoner ML, Fowler BV, Fear MW (2007) The use of a non-cultured autologous cell suspension and Integra dermal regeneration template to repair full-thickness skin wounds in a porcine model: a one-step process. Burns 33 693-700.

46. Radu CA, Gazyakan E, Germann G, Riedel K, Reichenberger M, et al. (2011) Optimizing Suprathel(R)-therapy by the use of Octenidine-Gel(R). Burns 37 294-298.

47. Schwarze H, Küntscher M, Uhlig C, Hierlemann H, Prantl L, et al. (2008) Suprathel, a new skin substitute, in the management of partial-thickness burn wounds: results of a clinical study. Ann Plast Surg 60: 181-185.

48. Uhlig C, Rapp M, Hartmann B, Hierlemann H, Planck H, et al. (2007) Suprathelan innovative, resorbable skin substitute for the treatment of burn victims. Burns 33: 221-229.

49. Gordley K, Cole P, Hicks J, Hollier L (2009) A comparative, long term assessment of soft tissue substitutes: AlloDerm, Enduragen, and Dermamatrix J Plast Reconstr Aesthet Surg 62: 849-850.

50. Becker S, Saint-Cyr M, Wong C, Dauwe P, Nagarkar P et al. (2009) AlloDerm versus DermaMatrix in immediate expander-based breast reconstruction: a preliminary comparison of complication profiles and material compliance. Plast Reconstr Surg 123: 1-6; discussion 107-108.

51. Grigoryants V, Jane JA, Jr, Lin KY (2007) Salvage of a complicated myelomeningocele using collagen (Duragen) and dermal (Alloderm) matrix substitutes. Case report and review of the literature. Pediatr Neurosurg 43 512-515.

52. Danish SF, Samdani A, Hanna A, Storm P, Sutton L (2006) Experience with 
acellular human dura and bovine collagen matrix for duraplasty after posterior fossa decompression for Chiari malformations. J Neurosurg 104: 16-20.

53. Gryskiewicz JM (2008) Dorsal Augmentation with AlloDerm. Semin Plast Surg 22: $90-103$.

54. Truong AT, Kowal-Vern A, Latenser BA, Wiley DE, Walter RJ (2005) Comparison of dermal substitutes in wound healing utilizing a nude mouse model. J Burns Wounds 4: e4.

55. Whitaker IS, Worthington S, Jivan S and Phipps A (2007) The use of Biobrane by burn units in the United Kingdom: a national study. Burns 33: 1015-1020.

56. Smith DJ Jr (1995) Use of Biobrane in wound management. J Burn Care Rehabil 16: 317-320.

57. Yang JY, Tsai YC, Noordhoff MS (1989) Clinical comparison of commercially available Biobrane preparations. Burns 15: 197-203.

58. Morykwas MJ, Thornton JW, Bartlett RH (1987) Zeta potential of synthetic and biological skin substitutes: effects on initial adherence. Plast Reconstr Surg 79: $732-739$

59. Sclafani AP, Romo T 3rd, Jacono AA (2002) Rejuvenation of the aging lip with an injectable acellular dermal graft (Cymetra). Arch Facial Plast Surg 4: 252257

60. Vacher D (2005) [Cell therapy product (Dermagen) for treatment of hard-toheal skin wounds]. Ann Pharm Fr 63: 207-210.

61. Raguse JD, Gath HJ (2005) A metabolically active dermal replacement (Dermagraft) for vestibuloplasty. J Oral Rehabil 32: 337-340.

62. Marston WA, Hanft J, Norwood P, Pollak R (2003) The efficacy and safety of Dermagraft in improving the healing of chronic diabetic foot ulcers: results of a prospective randomized trial. Diabetes Care 26: 1701-1705.

63. Economou TP, Rosenquist MD, Lewis RW 2nd, Kealey GP (1995) An experimental study to determine the effects of Dermagraft on skin graft viability in the presence of bacterial wound contamination. J Burn Care Rehabil 16: $27-30$.

64. Bello YM, Falabella AF, Eaglstein WH (2001) Tissue-engineered skin. Current status in wound healing. Am J Clin Dermatol 2: 305-313.

65. Healy CM, Boorman JG (1989) Comparison of E-Z Derm and Jelonet dressings for partial skin thickness burns. Burns Incl Therm Inj 15: 52-54.

66. Sahota PS, Burn JL, Heaton M, Freedlander E, Suvarna SK, et al. (2003) Development of a reconstructed human skin model for angiogenesis. Wound Repair Regen 11: 275-284.

67. Richters CD, Pirayesh A, Hoeksema H, Kamperdijk EW, Kreis RW, et al. (2008) Development of a dermal matrix from glycerol preserved allogeneic skin. Cell Tissue Bank 9: 309-315.

68. Snyder SJ, Arnoczky SP, Bond JL, Dopirak R (2009) Histologic evaluation of a biopsy specimen obtained 3 months after rotator cuff augmentation with GraftJacket Matrix. Arthroscopy 25: 329-333

69. Brigido SA (2006) The use of an acellular dermal regenerative tissue matrix in the treatment of lower extremity wounds: a prospective 16-week pilot study. Int Wound J 3: 181-187.

70. Martin BR, Sangalang M, Wu S, Armstrong DG (2005) Outcomes of allogenic acellular matrix therapy in treatment of diabetic foot wounds: an initial experience. Int Wound J 2: 161-165.

71. Stark HJ, Boehnke K, Mirancea N, Willhauck MJ, Pavesio A, et al. (2006) Epidermal homeostasis in long-term scaffold-enforced skin equivalents. J Investig Dermatol Symp Proc 11: 93-105.

72. Willhauck MJ, Mirancea N, Vosseler S, Pavesio A, Boukamp P, et al. (2007) Reversion of tumor phenotype in surface transplants of skin SCC cells by scaffold-induced stroma modulation. Carcinogenesis 28: 595-610.

73. Flasza M, Kemp P, Shering D, Qiao J, Marshall D, et al. (2007) Development and manufacture of an investigational human living dermal equivalent (ICXSKN). Regen Med 2: 903-918.

74. Boyd M, Flasza M, Johnson PA, Roberts JS, Kemp P (2007) Integration and persistence of an investigational human living skin equivalent (ICX-SKN) in human surgical wounds. Regen Med 2: 363-370.

75. Anderson JR, Fear MW, Phillips JK, Dawson LF, Wallace H, et al. (2011) A preliminary investigation of the reinnervation and return of sensory function in burn patients treated with INTEGRA((R)).Burns

76. Knobloch K, Vogt PM (2011) Integra, negative-pressure wound therapy, triplenerve decompression, and the reconstructive ladder in diabetic patients with ulcerations. Plast Reconstr Surg 127: 2134-2135.

77. Yan H, Black D, Jones NI, McCraw J, Chen H, et al. (2011) Integra Acellular Collagen as a Vascular Carrier for Skin Flap Prefabrication in Rats. Ann Plas Surg 67: 299-302.

78. Formigli L, Benvenuti S, Mercatelli R, Quercioli F, Tani A, et al. (2011) Derma matrix scaffold engineered with adult mesenchymal stem cells and platelet-rich plasma as a potential tool for tissue repair and regeneration. J Tissue Eng Regen Med

79. Schiestl C, Neuhaus K, Biedermann T, Böttcher-Haberzeth S, Reichmann E, et al. (2011) Novel treatment for massive lower extremity avulsion injuries in children: slow, but effective with good cosmesis. Eur J Pediatr Surg 21: 106110

80. Moiemen N, Yarrow J, Hodgson E, Constantinides J, Chipp E, et al. (2011) Long-term clinical and histological analysis of Integra dermal regeneration template. Plast Reconstr Surg 127: 1149-1154

81. Weigert R, Choughri H, Casoli V (2011) Management of severe hand wounds with Integra(R) dermal regeneration template. J Hand Surg Eur Vol 36: 185193

82. Onesti MG, Dessy LA, Fino P, Scuderi N (2011) Use of Integra(R) derma substitute in the treatment of complex wounds caused by antiblastic extravasation injury. J Plast Reconstr Aesthet Surg 64: e57-59.

83. Cervelli V, Lucarini L, Cerretani C, Spallone D, Palla L, et al. (2010) The use of Matriderm and autologous skin grafting in the treatment of diabetic ulcers: a case report. Int Wound J 7: 291-296.

84. Waaijman T, Breetveld M, Ulrich M, Middelkoop E, Scheper RJ, et al. (2010) Use of a collagen-elastin matrix as transport carrier system to transfer proliferating epidermal cells to human dermis in vitro. Cell Transplant 19: 1339-1348.

85. Ryssel H, Germann G, Czermak C, Kloeters O, Gazyakan E, et al. (2010) Matriderm $(R)$ in depth-adjusted reconstruction of necrotising fasciitis defects. Burns 36: 1107-1111.

86. Atherton DD, Tang R, Jones I, Jawad M (2010) Early excision and application of matriderm with simultaneous autologous skin grafting in facial burns. Plas Reconstr Surg 125: 60e-61e.

87. Boyce A, Atherton DD, Tang R, Jawad M (2010) The use of Matriderm in the management of an exposed Achilles tendon secondary to a burns injury. $J$ Plast Reconstr Aesthet Surg 63: e206-207.

88. Ryssel H, Gazyakan E, Germann G, Ohlbauer M (2008) The use of MatriDerm in early excision and simultaneous autologous skin grafting in burns--a pilot study. Burns 34: 93-97.

89. Hodde JP, Ernst DM, Hiles MC (2005) An investigation of the long-term bioactivity of endogenous growth factor in OASIS Wound Matrix. J Wound Care 14: 23-25.

90. Mostow EN, Haraway GD, Dalsing M, Hodde JP, King D (2005) Effectivenes of an extracellular matrix graft (OASIS Wound Matrix) in the treatment of chronic leg ulcers: a randomized clinical trial. J Vasc Surg 41: 837-843.

91. Niezgoda JA, Van Gils CC, Frykberg RG, Hodde JP (2005) Randomized clinica trial comparing OASIS Wound Matrix to Regranex Gel for diabetic ulcers. Adv Skin Wound Care 18: 258-266.

92. Hsu PW, Salgado CJ, Kent K, Finnegan M, Pello M, et al. (2009) Evaluation of porcine dermal collagen (Permacol) used in abdominal wall reconstruction. $J$ Plast Reconstr Aesthet Surg 62: 1484-1489.

93. Shevchenko RV, Sibbons PD, Sharpe JR, James SE (2008) Use of a nove porcine collagen paste as a dermal substitute in full-thickness wounds. Wound Repair Regen 16: 198-207.

94. Saray A (2003) Porcine dermal collagen (Permacol) for facial contou augmentation: preliminary report. Aesthetic Plast Surg 27: 368-375.

95. Crivellaro S, Smith JJ, Kocjancic E, Bresette JF (2004) Transvaginal sling using acellular human dermal allograft: safety and efficacy in 253 patients. J Urol 172 1374-1378.

96. Eisenberg T (2011) Implant Exposure Through a Breast Augmentation Incision 
Repaired with Porcine Acellular Dermal Matrix (Strattice(TM)): A Technique to Ensure Graft Take. Aesthetic Plast Surg 35: 681-3.

97. Mulier KE, Nguyen AH, Delaney JP, Marquez S (2011) Comparison of Permaco and Strattice for the repair of abdominal wall defects. Hernia 15: 315-319.

98. Katerinaki E, Zanetto U, Sterne GD (2010) Histological appearance of Strattice tissue matrix used in breast reconstruction. J Plast Reconstr Aesthet Surg 63: e840-841.

99. Parra MW, Rodas EB, Niravel AA (2010) Laparoscopic repair of potentially contaminated abdominal ventral hernias using a xenograft: a case series. Hernia 15: 575-578.

100. Pirayesh A, Dur AH, Paauw NJ, Monstrey S, Kreis RW, et al. (2008) Evaluation of acellular dermis for closure of abdominal wall defects in a rat model. Eur Surg Res 41: 346-352.

101.Lee KC, Lee NH, Ban JH, Jin SM (2008) Surgical treatment using an allograft dermal matrix for nasal septal perforation. Yonsei Med J 49: 244-248.

102. Amani H, Dougherty WR, Blome-Eberwein S (2006) Use of Transcyte and dermabrasion to treat burns reduces length of stay in burns of all size and etiology. Burns 32: 828-832.

103. Kumar RJ, Kimble RM, Boots R, Pegg SP (2004) Treatment of partialthickness burns: a prospective, randomized trial using Transcyte. ANZ J Surg 74: 622-626.

104. Johnson PA, Chavanu KE, Newman KD (2002) Guiding practice improvements in pediatric surgery using multidisciplinary clinical pathways. Semin Pediatr Surg 11: 20-24

105. Pape SA, Byrne PO (2000) Safety and efficacy of TransCyte for the treatment of partial-thickness burns. J Burn Care Rehabil 21: 390.

106. Demling RH, DeSanti L (1999) Management of partial thickness facial burns (comparison of topical antibiotics and bio-engineered skin substitutes). Burns 25: 256-261.

107. Cavorsi J, Vicari F, Wirthlin DJ, Ennis W, Kirsner R, et al. (2006) Bestpractice algorithms for the use of a bilayered living cell therapy (Apligraf) in the treatment of lower-extremity ulcers. Wound Repair Regen 14: 102-109.

108. Sibbald RG, Torrance GW, Walker V, Attard C, MacNeil P (2001) Costeffectiveness of Apligraf in the treatment of venous leg ulcers. Ostomy Wound Manage 47: 36-46.

109. Dinh TL, Veves A (2006) The efficacy of Apligraf in the treatment of diabetic foot ulcers. Plast Reconstr Surg 117: 152S-157S; discussion 158S-159S.

110. Windsor ML, Eisenberg M, Gordon-Thomson C, Moore GP (2009) A nove model of wound healing in the SCID mouse using a cultured human skin substitute. Australas J Dermatol 50: 29-35.

111. Still J, Glat P, Silverstein P, Griswold J, Mozingo D (2003) The use of a collagen sponge/living cell composite material to treat donor sites in burn patients. Burns 29: 837-841.

112. MacNeil S (2007) Progress and opportunities for tissue-engineered skin. Nature 445: 874-880.

113. Boyce ST, Kagan RJ, Greenhalgh DG, Warner P, Yakuboff KP, et al. (2006) Cultured skin substitutes reduce requirements for harvesting of skin autograft for closure of excised, full-thickness burns. J Trauma 60: 821-829.

114. Xiao YL, Riesle J, Van Blitterswijk CA (1999) Static and dynamic fibroblas seeding and cultivation in porous PEO/PBT scaffolds. J Mater Sci Mater Med 10: 773-777.

115. van Dorp AG, Verhoeven MC, Koerten HK, van Blitterswijk CA, Ponec M (1999) Bilayered biodegradable poly(ethylene glycol)/poly(butylene terephthalate) copolymer (Polyactive) as substrate for human fibroblasts and keratinocytes. J Biomed Mater Res 47: 292-300.

116. Beumer GJ, van Blitterswijk CA, Ponec M (1994) Biocompatibility of a biodegradable matrix used as a skin substitute: an in vivo evaluation. $J$ Biomed Mater Res 28: 545-552.

117. Beumer GJ, van Blitterswijk CA, Bakker D, Ponec M (1993) A new biodegradable matrix as part of a cell seeded skin substitute for the treatment of deep skin defects: a physico-chemical characterisation. Clin Mater 14: 21 27.

118. Centanni JM, Straseski JA, Wicks A, Hank JA, Rasmussen CA, et al. (2011)
StrataGraft skin substitute is well-tolerated and is not acutely immunogenic in patients with traumatic wounds: results from a prospective, randomized, controlled dose escalation trial. Ann Surg 253: 672-683.

119. Schurr MJ, Foster KN, Centanni JM, Comer AR, Wicks A, et al. (2009) Phase I/II clinical evaluation of StrataGraft: a consistent, pathogen-free human skin substitute. J Trauma 66: 866-873; discussion 873-874.

120. Bianchini C, Pelucchi S, Galassi G, Mandrioli G, Ciorba A, et al. (2008) Use of autologous dermal graft in the treatment of parotid surgery wounds for prevention of neck scars: preliminary results. J Otolaryngol Head Neck Surg 37: 174-178.

121.Black AF, Bouez C, Perrier E, Schlotmann K, Chapuis F, et al. (2005) Optimization and characterization of an engineered human skin equivalent. Tissue Eng 11:723-733.

122. Michel M, L'Heureux N, Pouliot R, Xu W, Auger FA, et al. (1999) Characterization of a new tissue-engineered human skin equivalent with hair. In Vitro Cell Dev Biol Anim 35: 318-326.

123. Pouliot R, Larouche D, Auger FA, Juhasz J, Xu W, et al. (2002) Reconstructed human skin produced in vitro and grafted on athymic mice. Transplantation 73: $1751-1757$.

124. Larouche D, Jean J, Berthod F, Germain L, Pouliot R, (2010) Markers for an in vitro skin substitute, in Alternative technologies to animal testing, T.M.a.E. Novik, Editor.: Boston. p. 283.

125. Hadgraft J (2001) Skin, the final frontier. Int J Pharm 224: 1-18.

126. Bellemare J, Roberge CJ, Bergeron D, Lopez-Vallé CA, Roy M, et al. (2005) Epidermis promotes dermal fibrosis: role in the pathogenesis of hypertrophic scars. J Pathol 206: 1-8.

127. Corriveau MP, Boufaied I, Lessard J, Chabaud S, Senécal JL, et al. (2009) The fibrotic phenotype of systemic sclerosis fibroblasts varies with disease duration and severity of skin involvement: reconstitution of skin fibrosis development using a tissue engineering approach. J Pathol 217: 534-542.

128. Labbe B, Marceau-Fortier G, Fradette J (2011) Cell sheet technology for tissue engineering: the self-assembly approach using adipose-derived stromal cells. Methods Mol Biol 702: 429-441.

129. Trottier V, Marceau-Fortier G, Germain L, Vincent C, Fradette J (2008) IFATS collection: Using human adipose-derived stem/stromal cells for the production of new skin substitutes. Stem Cells 26: 2713-2723.

130. Vallee M, Cote JF, Fradette J (2009) Adipose-tissue engineering: taking advantage of the properties of human adipose-derived stem/stromal cells. Pathol Biol (Paris) 57: 309-317.

131. Vermette M, Trottier V, Ménard V, Saint-Pierre L, Roy A, et al. (2007) Production of a new tissue-engineered adipose substitute from human adipose-derived stromal cells. Biomaterials 28: 2850-2860.

132. Rochon MH, Fradette J, Fortin V, Tomasetig F, Roberge CJ, et al. (2010) Normal human epithelial cells regulate the size and morphology of tissueengineered capillaries. Tissue Eng Part A 16: 1457-1468.

133. Proulx S, Fradette J, Gauvin R, Larouche D, Germain L (2010) Stem cells of the skin and cornea: their clinical applications in regenerative medicine. Cur Opin Organ Transplant [Epub ahead of print]

134. Larouche D, Paquet C, Fradette J, Carrier P, Auger FA, et al. (2009) Regeneration of skin and cornea by tissue engineering. Methods Mol Biol 482: 233-256.

135. Larouche D, Lavoie A, Proulx S, Paquet C, Carrier P, et al. (2009) [Regenerative medicine: stem cells, cellular and matricial interactions in the reconstruction of skin and cornea by tissue engineering]. Pathol Biol (Paris) 57: 299-308.

136. Paquet C, Larouche D, Bisson F, Proulx S, Simard-Bisson C, et al. (2010) Tissue engineering of skin and cornea: Development of new models for in vitro studies. Ann N Y Acad Sci 1197:166-177

137. Jean J, Soucy J, Pouliot R (2011) Effects of Retinoic Acid in Keratinocyte Proliferation and Differentiation in a Psoriatic Skin Model. Tissue Eng Part A 17: $1859-1868$

138. Jean J, Pouliot R, In vivo and in vitro models of psoriasis, in Tissue engineering D. Eberli, Editor. 2010. p. 359-382

139. L'Heureux N, Paquet S, Labbe R, Germain L, Auger FA (1998) A completely biological tissue-engineered human blood vessel. FASEB J 12: 47-56. 
Citation: Jean J, Garcia-Pérez ME, Pouliot R (2011) Bioengineered Skin: The Self-Assembly Approach. J Tissue Sci Eng S5:001. doi:10.4172/21577552.S5-001

140. Magnan M, Berthod F, Champigny MF, Soucy F, Bolduc S (2006) In vitro reconstruction of a tissue-engineered endothelialized bladder from a single porcine biopsy. J Pediatr Urol 2: 261-270.

141. Bouhout S, Perron E, Gauvin R, Bernard G, Ouellet G, et al. (2010) In vitro reconstruction of an autologous, watertight, and resistant vesical equivalent. Tissue Eng Part A 16: 1539-1548.

142. Magnan M, Lévesque P, Gauvin R, Dubé J, Barrieras D, et al. (2009) Tissue engineering of a genitourinary tubular tissue graft resistant to suturing and high internal pressures. Tissue Eng Part A 15: 197-202.

143. Ouellet G, Dubé J, Gauvin R, Laterreur V, Bouhout S, et al. (2011) Production of an optimized tissue-engineered pig connective tissue for the reconstruction of the urinary tract. Tissue Eng Part A 17: 1625-1633.

144. Proulx S, d'Arc Uwamaliya J, Carrier P, Deschambeault A, Audet C, et al. (2010) Reconstruction of a human cornea by the self-assembly approach of tissue engineering using the three native cell types. Mol Vis 16: 2192-2201.

This article was originally published in a special issue, Novel Substitutes and Restorative Materials handled by Editor(s). Dr. Heather Fahlenkamp, Oklahoma State University, USA; Dr. Sanjukta Deb, Dental Institute, UK; Dr. Yadong Wang, University of Pittsburgh, USA 